DOI: 10.19195/0524-4544.327.13

\author{
RAFAŁ CZACHOR \\ ORCID: 0000-0002-5929-9719 \\ Uczelnia Jana Wyżykowskiego \\ r.czachor@ujw.pl
}

\title{
Obowiązki konstytucyjne w państwach postradzieckich
}

\begin{abstract}
Abstrakt: Obowiązki, wraz z prawami i wolnościami, określają pozycję prawną jednostki w państwie. Również w praktyce większe znaczenie zwykło się nadawać prawom i wolnościom niż obowiązkom. Mimo to zasadne wydaje się analizowanie ich treści. Niniejszy artykuł omawia obowiązki konstytucyjne w państwach postradzieckich. Przenalizowano i porównano zarówno liczbę obowiązków w poszczególnych republikach, jak i ich treść.
\end{abstract}

Słowa kluczowe: państwa postradzieckie, prawo konstytucyjne państw postradzieckich, obowiązki konstytucyjne, prawo porównawcze.

\section{Uwagi wstępne}

Obowiązki, obok praw i wolności, stanowią kluczowy element określający konstytucyjny status jednostki w państwie. Jednakże w literaturze przedmiotu tym pierwszym poświęca się relatywnie mało uwagi, priorytetowo traktując zagadnienie praw i wolności, ich regulacji i gwarancji przestrzegania. Również w praktyce większe znaczenie zwykło się nadawać prawom i wolnościom niż obowiązkom. Z zasadnością powyższego można polemizować, natomiast poniekąd uzasadnieniem może być pogląd, iż rudymentarne interesy i potrzeby człowieka realizowane są w domenie praw, a dopiero wtórnie w domenie obowiązków. Celem niniejszego artykułu jest charakterystyka obowiązków konstytucyjnych w republikach powstałych w związku z rozpadem Związku Radzieckiego. Zagadnienie to nie było do tej pory podejmowane w polskiej literaturze przedmiotu. Analiza o charakterze porównawczym ma charakter zarówno ilościowy, jak i jakościowy: 
przeanalizowano ilość obowiązków nakładanych przez ustrojodawców oraz ich zakres podmiotowy i przedmiotowy. Zasadnicza teza artykułu sprowadza się do twierdzenia o istnieniu podstawowego kanonu obowiązków zawartych w konstytucjach omawianych państw, obecnego również w ustrojach innych krajów, przy zachowaniu własnej specyfiki poszczególnych republik. Formalnie regulacje w tej materii pozostają zgodne z takimi zasadami ustrojowymi jak istnienie państwa prawa opartego na sprawiedliwości społecznej.

Oczywiste i bezsporne wydaje się to, że dychotomicznie traktowane prawa i obowiązki wzajemnie uzupełniają się, stanowiąc jeden z fundamentów każdego systemu prawa, w tym systemu prawa konstytucyjnego. Zasadniczo katalog konstytucyjnych norm regulujących prawa jest szerszy niż katalog obowiązków, niezależnie o jakim państwie świata jest mowa. Niektóre z nich mają charakter moralny, pozbawione są sankcji, co różni je od obowiązków prawnych, uregulowanych w ustawach. Istnienie praw przy braku obowiązków, bądź ich szczątkowym uregulowaniu, oznaczałoby chaos i dysfunkcjonalność instytucji publicznych. Właściwe określenie praw i obowiązków oraz ich wzajemnych relacji jest niezbędnym elementem sprawnego państwa demokratycznego. Problem ten jest szczególnie istotny w państwach transformujących swój ustrój i przechodzących od reżimu niedemokratycznego (totalitarnego bądź autorytarnego) do demokratycznego. Istotne, że w doktrynie konstatuje się brak niepodważalnej definicji obowiązków. Za Bogusławem Banaszakiem można powtórzyć, że jest to konstytucyjny zbiór

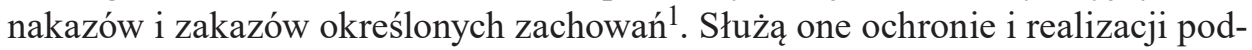
stawowych dla społeczności dóbr, dlatego też nie powinny być wąsko rozumiane jako nakaz bądź zakaz określonego zachowania ${ }^{2}$. Określając katalog obowiązków, na ustrojodawcy spoczywa również zadanie stworzenia warunków umożliwiających ich realizację. Można przychylić się do poglądu, iż konstytucyjnie uregulowane prawa człowieka i obywatela są określonym celem funkcjonowania instytucji publicznych, normatywne uregulowanie obowiązków zaś — środkiem służącym osiągnięciu tego celu ${ }^{3}$. $\mathrm{Z}$ tego powodu, mimo że kultura prawna państw demokratycznych zorientowana jest na prawa i wolności oraz ich ochronę ${ }^{4}$, obowiązki należy traktować zarówno jako istotny element prawa ustrojowego, jak i ważny obszar badawczy. W przypadku petryfikujących swój niezależny byt polityczny republik postradzieckich zagadnienie statusu jednostki (określane poprzez prawa i obowiązki) wydaje się szczególnie ważne.

1 B. Banaszak, Prawo konstytucyjne, Warszawa 2010, s. 507.

2 K. Działocha, Obowiazki, [w:] Konstytucja Rzeczypospolitej Polskiej. Komentarz, t. 3, red. L. Garlicki, Warszawa 2003, s. 6-9.

${ }^{3}$ I.A. Alebastrova, Konstitucionnye obâzannosti čeloveka i graždanina: značenie i tendencii razvitiâ, „Konstitucionnoe i municipal'noe pravo” 2016, nr 12, s. 22-25.

${ }^{4}$ M. Zieliński, Obowiązki konstytucyjne a ustrój państwa, [w:] Aktualne wyzwania ochrony wolności i praw jednostki: prace uczniów i wspótpracowników dedykowane Profesorowi Bogusławowi Banaszakowi, red. M. Jabłoński, S. Jarosz-Żukowska, Wrocław 2014, s. 399-400. 


\section{Radzieckie konstytucyjne regulacje obowiązków jednostki}

Zagadnienia praw i obowiązków w prawie konstytucyjnym państw postradzieckich $^{5}$ są regularnie podejmowane przez badaczy z tego obszaru ${ }^{6}$, ogółem zaś w doktrynie stwierdza się ciągłe poszukiwanie przez te państwa modelu ustrojowego i gwarancji przynależnych jednostkom. Za wspólny punkt wyjścia konstytucjonalizmu omawianych państw należy przyjąć doświadczenie ustrojowe okresu Związku Radzieckiego. Konstytucja ZSRR z 1924 roku ${ }^{7}$ nie wprowadzała ogólnozwiązkowych norm regulujących problem praw i obowiązków, cedując te kwestie na poszczególne republiki składowe. Przykładowo ustawa zasadnicza Rosyjskiej Socjalistycznej Federacyjnej Republiki Radzieckiej z 1925 roku ${ }^{8}$ powtórzyła w tej materii regulacje z poprzedniej konstytucji — z 1918 roku$^{9}$. Wprowadzono wówczas dwa obowiązki nakładane na jednostki: obowiązek pracy i służby wojskowej. Konstytucja ZSRR z 1936 roku $^{10}$ zawierała już rozdział Podstawowe prawa $i$ wolności, w którym znajdował się względnie szeroki katalog obowiązków. Obok istniejących już obowiązków pracy i służby wojskowej wprowadzono obowiązki: przestrzegania konstytucji, rzetelnego wypełniania obowiązków społecznych, poszanowania zasad socjalistycznego współżycia społecznego, poszanowania i wzmacniania własności społecznej. Ostatnia ustawa zasadnicza ZSRR

5 Pod pojęciem państw postradzieckich rozumie się tutaj republiki powstałe w wyniku rozpadu Związku Radzieckiego z wyjątkiem Litwy, Łotwy i Estonii, których ewolucja ustroju i zasad regulujących funkcjonowanie systemu politycznego od 1990 roku zdecydowanie odbiegała od procesów zachodzących w pozostałych częściach składowych ZSRR. Litwa, Łotwa i Estonia, w odróżnieniu od republik postradzieckich, stanowią obecnie reżimy polityczne klasyfikowane przez politologów jako w pełni demokratyczne.

${ }^{6}$ Z najnowszych publikacji: N.I. Matuzov, Obâzannosti čeloveka i graždanina kak uslovie demokratii i social'noj stabil'nosti, „Pravovaâ kul'tura” 2015, nr 49 (23); M.V. Čistûhina, Obâzannosti čeloveka i graždanina v konstituciâh stran Sodružestva nezavisimyh gosudarstv, „Nauka i obrazovanie: hozâjstvo i èkonomika; predprinimatel'stvo; pravo i upravlenie" 2017, nr 7 (86); N.V. Anciferov, Konstitucionnoe zakreplenie obâzannostej ličnosti v stranah postsovetskogo prostranstva: sravnitel'no-pravovoj analiz, „Üridičeskie issledovaniâ” 2017, $\mathrm{nr} 8$.

${ }^{7}$ Konstituciâ (Osnovnoj Zakon) Soûza Sovetskih Socialističeskih Respublik (utverždena II S"ezdom Sovetov Soûza SSR ot 31 ânvarâ 1924 g.), http://constitution.garant.ru/history/ussr-rsfsr/1924/red_1924/5508660/(dostęp: 8.12.2018).

${ }^{8}$ Konstituciâ (Osnovnoj zakon) Rossijskoj Socialističeskoj Federativnoj Sovetskoj Respubliki (utverždena postanovleniem XII Vserossijskogo S"ezda Sovetov ot 11 maâ 1925 g.), http://constitution.garant.ru/history/ussr-rsfsr/1925/red_1925/185477/chapter/3c1d312a9c6c4a13a02d7900fa6f 03a9/ (dostęp: 8.12.2018).

9 Konstituciâ RSFSR 1918 goda, Moskva 2003.

10 Konstituciâ (Osnovnoj zakon) Soûza Sovetskih Socialističeskih Respublik (utverždena postanovleniem Črezvyčajnogo VIII S"ezda Sovetov Soûza Sovetskih Socialističeskih Respublik ot 5 dekabrâ 1936 g.), http://constitution.garant.ru/history/ussr-rsfsr/1936/red_1936/3958676/ (dostęp: 8.12.2018). 
z 1977 roku $^{11}$ zawierała jeszcze bardziej uszczegółowiony katalog obowiązków. Były to, oprócz wcześniej wspomnianych, obowiązek poszanowania godności narodowej współobywateli, wzmacniania przyjaźni narodów zamieszkujących ZSRR, poszanowania praw i interesów innych, nieakceptowania czynów antyspołecznych, współdziałania na rzecz porządku publicznego, troski o wychowanie dzieci i przygotowania ich do pracy, bycia wartościowymi obywatelami, troski o rodziców i wspierania ich, poszanowania i ochrony środowiska, obiektów o wartości historycznej i kulturowej, współdziałania na rzecz współpracy z narodami innych państw, wspierania powszechnego pokoju. Adresatami wszystkich norm byli obywatele ZSRR ${ }^{12}$.

Wszystkie republiki postradzieckie własne konstytucje przyjęły w pierwszej połowie lat 90. XX wieku. Najwcześniej uczynił to Turkmenistan — 18 maja 1992 roku $^{13}$, następnie: Uzbekistan — 8 grudnia 1992 roku $^{14}$; Kazachstan — 18 stycznia 1993 roku (kolejna konstytucja była przyjęta 30 sierpnia 1995 roku) ${ }^{15}$; Kirgistan 5 maja 1993 roku (zastąpiona nową konstytucją 27 czerwca 2010 roku) $)^{16}$; Rosja — 25 grudnia 1993 roku $^{17}$; Białoruś - 15 marca 1994 roku $^{18}$; Mołdawia — 27 sierpnia 1994 roku $^{19}$; Tadżykistan — 6 listopada 1994 roku $^{20}$; Armenia — 5 lipca 1995 roku $^{21}$; Gruzja - 24 sierpnia 1995 roku $^{22}$; Azerbejdżan — 12 listopada 1995 roku ${ }^{23}$; natomiast ostatnim państwem była Ukraina - 28 czerwca 1996 roku $^{24}$. We wszystkich republikach konstytucja jest definiowana jako najwyższy akt prawny państwa, w Mołdawii zaś — „najwyższy akt prawny społeczeństwa i państwa”25.

11 Konstytucja (Ustawa Zasadnicza) Związku Socjalistycznych Republik Radzieckich, Warszawa 1977.

12 V.P. Ŝennikov, N.V. Anciferov, Üridičeskie obâzannosti v sisteme konstitucii, „Vestnik Kemerovskogo gosudarstvennogo universiteta" 2, 2015, nr 1 (61), s. 250-251.

13 Konstituciâ Turkmenistana, http://turkmenistan.gov.tm/?id=11808 (dostęp: 10.12.2018).

14 Konstituciâ Respubliki Uzbekistan, http://constitution.uz/ru/clause/index (dostęp: 10.12.2018).

15 Konstituciâ Respubliki Kazahstan, http://www.constitution.kz (dostęp: 10.12.2018).

${ }^{16}$ Konstituciâ Kyrgyzskoj Respubliki, www.gov.kg/?page_id=263\&lang=ru (dostęp: 10.12.2018).

17 Konstytucja Federacji Rosyjskiej, wstęp A. Bosiacki, Warszawa 2000.

18 Konstituciâ Respubliki Belarus', Minsk 1994.

19 Konstytucja Republiki Mołdawii, wstęp B. Zdaniuk, Warszawa 2014.

${ }^{20}$ Konstituciâ Respubliki Tadžikistan, http://www.president.tj/ru/taxonomy/term/5/112 (dostęp: 10.12.2018).

${ }^{21}$ Konstituciâ Respubliki Armeniâ, http://www.parliament.am/legislation.php?sel=show\& ID=1\&lang=rus (dostęp: 9.12.2018).

22 Konstytucja Gruzji, wstęp G. Kuca, M. Grzybowski, Warszawa 2015.

23 Konstituciâ Azerbajdžanskoj Respubliki, http://www.azerbaijan.az/portal/General/Constitution/doc/constitution_r.pdf (dostęp: 9.12.2018).

${ }^{24}$ Konstytucja Ukrainy, wstęp E. Toczek, Warszawa 1999.

25 R. Czachor, Tryb i praktyka zmiany konstytucji w państwach postradzieckich w ujęciu porównawczym, [w:] Dwadzieścia lat obowiazywania konstytucji RP. Polska myśl konstytucyjna a międzynarodowe standardy demokratyczne, red. J. Jaskiernia, K. Spryszak, Toruń 2017, s. 836-837. 
Akty te w wielu przypadkach były kilkukrotnie nowelizowane. Zmiany dotyczyły przede wszystkim pozycji ustrojowej głównych organów państwa - prezydenta, parlamentu i rządu — oraz ich wzajemnych relacji. Katalogi praw i obowiązków nie podlegały modyfikacjom.

\section{Analiza porównawcza obowiązków konstytucyjnych we współczesnych konstytucjach państw postradzieckich}

Analiza konstytucji republik postradzieckich prowadzi do konkluzji, że choć wszystkie z nich zawierają określony — mniej lub bardziej rozbudowany — katalog obowiązków, są one rozmaicie umieszczone w treści ustaw zasadniczych. Co do zasady są one sformułowane w rozdziałach dotyczących praw i wolności (konstytucje: Białorusi, Gruzji, Kazachstanu, Kirgistanu, Rosji, Tadżykistanu, Turkmenistanu i Ukrainy), w sporadycznych zaś przypadkach - w wyodrębnionych rozdziałach/podrozdziałach (Azerbejdżan, Mołdawia, Uzbekistan) bądź są rozproszone w treści konstytucji, znajdując się nawet wśród podstaw ustrojowych (Armenia). Wyodrębnienia rozdziału dotyczącego obowiązków nie należy utożsamiać z ich rozbudowanym katalogiem (przykład stanowi ustawa zasadnicza Mołdawii, której odpowiedni rozdział zawiera ledwie 4 obowiązki). Co do zasady umieszczone są po normach regulujących prawa i wolności. Tę sytuację można interpretować jako swoiste podporządkowanie konstytucyjnych obowiązków konstytucyjnym prawom i wolnościom. Podczas gdy większość obowiązków jest sformułowana explicite, część z nich należy rekonstruować z treści praw i gwarancji ich ochrony. Gdy konstytucje gwarantują nienaruszalność praw i wolności jednostki, należałoby uznać, iż jednocześnie niosą one powszechne zobowiązanie ich przestrzegania, zarówno ze strony organów władzy publicznej, jak i osób fizycznych. Uwaga zostanie poświęcona głównie tym obowiązkom, które jako takie zostały wprost unormowane.

Ustrojodawcy poszczególnych republik postradzieckich kwestii obowiązków poświęcili różną uwagę. Po pierwsze, przejawia się to w aspekcie ilościowym, którego wymierną ilustracją jest liczba artykułów ustaw zasadniczych dotyczących omawianej materii, po drugie w aspekcie jakościowym, to jest w zakresie podmiotowym i przedmiotowym. Ogółem konstytucje państw postradzieckich ze względu na kryterium ilościowe obowiązków można podzielić na: rozbudowane (7-8 obowiązków zdefiniowanych w konstytucji - Azerbejdżan, Rosja, Uzbekistan, Turkmenistan); umiarkowane (5-6 obowiązków - Armenia, Białoruś, Kazachstan, Tadżykistan) oraz ograniczone (4 obowiązki - Gruzja, Kirgistan, Mołdawia, Ukraina). Analiza liczby obowiązków unormowanych konstytucyj- 
nie w porównaniu do politologicznych badań poziomu demokracji wskazuje na istnienie określonej zależności - państwa, w których katalog obowiązków jest ilościowo skromny, są oceniane jako najbardziej demokratyczne spośród obszaru byłego ZSRR (w świetle Democracy Index 2017 są to: Gruzja, Mołdawia, Kirgistan i Ukraina).

Ustawy zasadnicze państw postradzieckich różnią się istotnie pomiędzy sobą zakresem obowiązków nakładanych na obywateli. W tym miejscu należy wskazać, że zakres podmiotów podległych tego typu normom konstytucyjnym jest odmienny zarówno w odniesieniu do poszczególnych państw, jak i do poszczególnych obowiązków. Najczęściej używane są kategorie „każdy” (co oznacza obywateli i nie-obywateli danego państwa), „obywatel” (co z jednej strony ogranicza krąg adresatów danej normy do osób mających obywatelstwo, z drugiej jednak z innych norm konstytucyjnych można wywieść domniemane rozciągnięcie tegoż katalogu na nie-obywateli). Niektóre konstytucyjne obowiązki dotyczą węższej, sprecyzowanej grupy adresatów: rodziców, dzieci, właścicieli majątku. Szczegółowo zostanie to wyjaśnione w dalszej części niniejszego artykułu. W przypadku konstytucji Kirgistanu, Rosji, Tadżykistanu, Turkmenistanu i Uzbekistanu wprowadzono stypulację nakazującą nie-obywatelom i apatrydom przestrzeganie obowiązków (ale również korzystanie z praw) na równi z ich obywatelami.

Analiza treści poszczególnych konstytucji pozwala na wydzielenie kilku podstawowych grup obowiązków: a) ogólny obowiązek przestrzegania prawa; b) obowiązek poszanowania praw i wolności innych jednostek; c) powszechny obowiązek obrony i służby wojskowej; d) obowiązek uiszczania podatków i innych danin publicznych; e) obowiązek ochrony środowiska naturalnego; f) obowiązek poszanowania dziedzictwa historycznego i kulturowego; g) obowiązki rodziców względem dzieci i dzieci względem rodziców.

Ad a) Ogólny obowiązek przestrzegania prawa jako obowiązek konstytucyjny zawiera 8 ustaw zasadniczych republik postradzieckich. Obowiązek ten nakładany jest na „każdego”, „człowieka” (Azerbejdżan, Białoruś, Gruzja, Kazachstan, Tadżykistan, Turkmenistan, Ukraina, Uzbekistan), bądź explicite tylko na obywateli (Rosja, Uzbekistan), choć w tym wypadku normy te należy interpretować w związku z innymi przepisami konstytucji zrównującymi w określonych okolicznościach sytuację prawną obywateli i nie-obywateli (art. 62 ust. 2 konstytucji Rosji i art. 23 konstytucji Uzbekistanu). Spośród omawianych konstytucji tylko ustawy zasadnicze Armenii, Mołdawii i Kirgistanu nie zawierają tego typu uregulowań. Z obowiązkiem przestrzegania prawa należy też wiązać obowiązek poszanowania symboli państwowych, który jest przewidziany w konstytucjach Azerbejdżanu i Kazachstanu, czy zakaz uzurpacji władzy (Azerbejdżan). W Armenii wprowadzono zakaz wykorzystywania praw i wolności jednostki w celu siłowej zmiany ustroju państwa, podżegania do nienawiści na tle rasowym, etnicznym, religijnym, szerzenia nienawiści i przemocy. W Kazachstanie zakazane jest występowanie przeciwko ustrojowi konstytucyjnemu i bezpieczeństwu publicznemu. 
Ad b) Nakaz poszanowania praw i wolności innych jednostek sformułowany w sposób dosłowny zawierają 3 analizowane konstytucje: Białorusi, Kazachstanu i Uzbekistanu. Regulacje z tego zakresu znajdują się także w innych ustawach zasadniczych i są sformułowane jako granice realizacji własnych praw i wolności w związku z interesem publicznym, będącym w istocie sumą interesów innych jednostek. Ustrojodawcy w tej materii używają zarówno zakazu „naruszania”, „ograniczania” „praw i wolności innych” (Gruzja, Kazachstan, Rosja, Turkmenistan, Ukraina, Uzbekistan), jak i mniej precyzyjnego obowiązku „poszanowania” „praw i wolności” (Azerbejdżan, Białoruś, Kazachstan, Tadżykistan). Do tego katalogu można zaliczyć również zakaz naruszania „ustawowo gwarantowanych interesów” innych osób (Białoruś, Uzbekistan) czy też „czci i godności” (Białoruś, Kazachstan, Tadżykistan, Ukraina, Uzbekistan).

Należy odnotować bardziej precyzyjne regulacje dotyczące tej kwestii w poszczególnych republikach. W Uzbekistanie z tego obowiązku wynika zakaz naruszania ,interesów i praw państwa oraz społeczeństwa”. W Turkmenistanie powyższy obowiązek połączono z zakazem naruszania zasad moralnych, porządku publicznego, wyrządzania szkody interesom bezpieczeństwa narodowego. Konstytucje Azerbejdżanu, Kazachstanu i Ukrainy wprowadzają nakaz poszanowania symboli państwowych. Niektóre z ustaw zasadniczych wprowadzają również szereg obowiązków względem dziedzictwa narodowego, co zostało omówione poniżej.

W powyższej kategorii mieści się również zawarty w konstytucjach 3 republik katalog obowiązków wynikających z prawa własności. Własność nie może być wykorzystywana ze szkodą dla interesów państwa, społeczeństwa, jednostek (Azerbejdżan, Białoruś, Uzbekistan).

Ad c) Powszechny obowiązek obrony wprowadzono do 10 ustaw zasadniczych. Tylko konstytucja Gruzji go nie zawiera. Odpowiednie normy są niekiedy sformułowane podniosłym językiem, operując pozaprawną kategorią „Ojczyzny” (Azerbejdżan, Kirgistan, Rosja, Tadżykistan, Ukraina). Często (konstytucje Azerbejdżanu, Kirgistanu, Rosji, Uzbekistanu) używa się także patetycznego pojęcia „powinności” (ros. dotg), a nie kategorii prawnej, to jest obowiązku (ros. objazannost'). W niektórych aktach używa się wręcz pojęcia ,świętego zobowiązania do obrony Ojczyzny" (Białoruś, Kazachstan, Tadżykistan, Turkmenistan). Oznacza to, że obrona jest świadczona na rzecz „Ojczyzny” i jest powinnością, a więc zobowiązaniem również o charakterze moralnym. Przykładowo konstytucja Mołdawii stanowi, że „obrona Ojczyzny jest prawem i świętym obowiązkiem każdego obywatela" (art. 57, ust. 1). Na Ukrainie obowiązek obrony ojczyzny połączono $\mathrm{z}$,obroną jej niepodległości, integralności terytorialnej i szacunkiem dla symboli państwowych” (art. 65). W przypadku Tadżykistanu jest to „święty obowiązek obrony Ojczyzny, ochrony interesów państwa, wzmocnienia jego niezależności, bezpieczeństwa i siły obronnej" (art. 43). Co do zasady obowiązkiem tym są objęci obywatele poszczególnych państw, a wyjątkiem jest konstytucja Kirgistanu, która 
obowiązek ten nakłada na „wszystkich”. Zasadniczo obowiązek obrony nie jest tożsamy z obowiązkiem powszechnej służby wojskowej. Kwestie te są regulowane ustawą i tylko konstytucje Turkmenistanu i Uzbekistanu wprowadzają obowiązek służby wojskowej dla mężczyzn. W unormowaniach rosyjskich obok obowiązku obrony pojawiają się odesłania do ustawy w kwestii służby wojskowej, jednakże nie jest ona wprost określona mianem obowiązku obywatelskiego. Z powyższym obowiązkiem połączyć można obowiązek wierności ojczyźnie, który jest normą konstytucyjną w Azerbejdżanie i Mołdawii.

Ad d) Obowiązek uiszczania podatków i innych danin publicznych zawierają wszystkie omawiane ustawy zasadnicze z wyjątkiem konstytucji Gruzji. Najczęściej zawierają one odesłanie do ustaw jako aktów precyzujących charakter i zakres zobowiązań tego typu (Azerbejdżan, Kirgistan, Rosja, Tadżykistan, Turkmenistan, Ukraina, Uzbekistan). Inne spotykane sformułowanie tegoż obowiązku (konstytucje Armenii, Białorusi i Mołdawii) to powiązanie ze sprecyzowaniem celu poboru podatków i danin. Przykładowo konstytucja Białorusi głosi, że celem jest „udział w finansowaniu wydatków państwowych”, Mołdawii zaś — „finansowanie wydatków publicznych". Niektóre konstytucje precyzują, iż obowiązek ten winien być realizowany „W pełni” (Azerbejdżan, Turkmenistan, Ukraina), „terminowo” (Azerbejdżan) czy „na określonych prawem zasadach” (Kirgistan, Turkmenistan, Ukraina). Ukraiński ustrojodawca dodatkowo do obowiązków konstytucyjnych zaliczył obowiązek corocznego składania deklaracji podatkowej.

Ad e) Obowiązek ochrony środowiska naturalnego wprowadzono we wszystkich 12 konstytucjach państw postradzieckich i dotyczy on wszystkich jednostek, niezależnie od jakichkolwiek kryteriów. Co do zasady sformułowany został on jako „obowiązek ochrony środowiska naturalnego” (Azerbejdżan, Białoruś, Kazachstan, Mołdawia, Tadżykistan, Turkmenistan). W innych przypadkach został określony jako „obowiązek ochrony świata roślin i zwierząt” (Kirgistan), „odpowiedzialny stosunek do przyrody (bogactw naturalnych)" (Kazachstan), ,obowiązek zachowania przyrody" (Rosja).

Ad f) Obowiązek poszanowania dziedzictwa historycznego i kulturowego obecny jest, w różnej postaci, w ustawach zasadniczych 8 państw. Jest to: „obowiązek poszanowania dziedzictwa historycznego i kulturowego" (Kazachstan, Rosja), „dziedzictwa historyczno-kulturowego, duchowego i wartości narodowych” (Białoruś), „dziedzictwa historycznego, duchowego i kulturowego”(Uzbekistan), „dziedzictwa kultury” (Ukraina) bądź „pomników historii i kultury” (Azerbejdżan). Nie zawierają go konstytucje Armenii, Kirgistanu i Mołdawii.

Ad g) Obowiązki rodziców względem dzieci i dzieci względem rodziców są dość specyficzną kategorią obowiązków obecną w ustawach zasadniczych 9 państw. W kategorii tej mieści się przede wszystkim zobowiązanie do ogólnej troski o dzieci (Azerbejdżan, Kazachstan, Rosja), o ich wychowanie (Azerbejdżan, Armenia, Białoruś, Kazachstan, Rosja, Tadżykistan, Turkmenistan, Uzbekistan), o stan ich zdrowia (Armenia, Białoruś, Turkmenistan) czy też o rozwój dzieci 
(Armenia, Białoruś). Niektóre konstytucje precyzują te obowiązki, np. konstytucja Armenii głosi obowiązek ,pełnowartościowego i harmonijnego rozwoju”, zaś ustawa zasadnicza Turkmenistanu — ,przygotowania do pracy, zaszczepienia kultury szacunku do prawa, historycznych i narodowych tradycji”.

Niektóre konstytucje zawierają też obowiązki dzieci wobec rodziców. Szerzej zagadnienie potraktowano w prawodawstwie Kirgistanu, gdzie obowiązki dzieci potraktowano szerzej jako obowiązki młodszych pokoleń wobec „starszych, krewnych i bliskich" (art. 37). W przypadku Rosji istnieją konstytucyjne obowiązki rodziców wobec dzieci, lecz nie ma konstytucyjnych obowiązków pełnoletnich dzieci wobec rodziców. Do obowiązków tych zaliczają się: szacunek dla rodziców (Azerbejdżan, Kirgistan — z powyższym zastrzeżeniem), troska o rodziców (Azerbejdżan, Armenia, Białoruś, Kazachstan, Kirgistan — troska o rodzinę i najbliższych, Rosja, Turkmenistan, Uzbekistan), utrzymanie rodziców (Azerbejdżan) czy też wsparcie i zabezpieczenie społeczne (Tadżykistan). Obowiązki te nakładane są przez ustrojodawców na dzieci pełnoletnie i zdolne do pracy (Armenia, Azerbejdżan, Kazachstan, Rosja, Tadżykistan, Uzbekistan), ich beneficjentami zaś są rodzice niezdolni do pracy (Azerbejdżan, Kazachstan, Rosja, w przypadku Armenii — niezdolni do pracy i wymagający wsparcia).

Warto odnotować, że konstytucja Rosji nakłada na rodziców lub opiekunów prawnych dzieci zapewnienie, by zrealizowały one obowiązek ukończenia szkoły podstawowej. W Gruzji wprowadzono normę konstytucyjną nakazującą pobieranie nauki na poziomie szkoły podstawowej i średniej.

\section{Podsumowanie}

Analiza pokazuje, że poszczególne republiki powstałe w wyniku rozpadu ZSRR przyjęły zróżnicowane katalogi konstytucyjnych obowiązków jednostki. Można tu przede wszystkim mówić o różnicach w zakresie obowiązków. Najbardziej ogólnikowe regulacje wprowadziła Mołdawia i Gruzja, najbardziej szczegółowo zaś obowiązki zdefiniowano w Azerbejdżanie i Uzbekistanie.

Ogółem obowiązki konstytucyjne w państwach postradzieckich można zaklasyfikować jako mające na celu: konsolidację państwa i zapewnienie porządku publicznego (np. ogólny nakaz przestrzegania prawa, służby wojskowej, uiszczania podatków), ochronę środowiska naturalnego i dziedzictwa historyczno-kulturowego, zagwarantowanie praw i wolności jednostki (np. zakaz naruszania praw przynależnych innym osobom), zapewnienie solidarności społecznej (np. obowiązki wobec rodziców).

Wszystkie ustawy zasadnicze państw postradzieckich zawierają obowiązek ochrony środowiska naturalnego, niemalże wszystkie z nich wprowadzają obowiązek uiszczania podatków i opłat, obrony państwa i ogólnego poszanowania 
prawa. W ponad połowie republik obowiązuje nakaz poszanowania dziedzictwa oraz troski międzypokoleniowej.

Wydaje się, że katalog konstytucyjnych obowiązków obywateli republik postradzieckich jest spójny i nie odbiega istotnie od rozwiązań obowiązujących w innych państwach.

\section{Bibliografia}

\section{Piśmiennictwo}

Alebastrova I.A., Konstitucionnye obâzannosti čeloveka i graždanina: značenie i tendencii razvitiâ, „Konstitucionnoe i municipal'noe pravo” 2016, nr 12.

Anciferov N.V., Konstitucionnoe zakreplenie obâzannostej ličnosti v stranah postsovetskogo prostranstva: sravnitel'no-pravovoj analiz, „Üridičeskie issledovaniâ” 2017, $\mathrm{nr} 8$.

Banaszak B., Prawo konstytucyjne, Warszawa 2010.

Czachor R., Tryb i praktyka zmiany konstytucji w państwach postradzieckich w ujęciu porównawczym, [w:] Dwadzieścia lat obowiazywania konstytucji RP. Polska myśl konstytucyjna a międzynarodowe standardy demokratyczne, red. J. Jaskiernia, K. Spryszak, Toruń 2017.

Čistûhina M.V., Obâzannosti čeloveka i graždanina v konstituciâh stran Sodružestva nezavisimyh gosudarstv, ,Nauka i obrazovanie: hozâjstvo i èkonomika; predprinimatel'stvo; pravo i upravlenie" 2017, nr 7 (86).

Działocha K., Obowiązki, [w:] Konstytucja Rzeczypospolitej Polskiej. Komentarz, t. 3, red. L. Garlicki, Warszawa 2003.

Matuzov N.I., Obâzannosti čeloveka i graždanina kak uslovie demokratii i social'noj stabil'nosti, „Pravovaâ kul'tura” 2015, nr 49 (23).

Ŝennikov V.P., Anciferov N.V., Üridičeskie obâzannosti v sisteme konstitucii, „Vestnik Kemerovskogo gosudarstvennogo universiteta" 2, 2015, $\mathrm{nr} 1$ (61).

Zieliński M., Obowiązki konstytucyjne a ustrój państwa, [w:] Aktualne wyzwania ochrony wolności i praw jednostki: prace uczniów i wspótpracowników dedykowane Profesorowi Bogusławowi Banaszakowi, red. M. Jabłoński, S. Jarosz-Żukowska, Wrocław 2014.

\section{Akty prawne}

Konstituciâ Azerbajdžanskoj Respubliki, http://www.azerbaijan.az/portal/General/Constitution/ doc/constitution_r.pdf (dostęp: 9.12.2018).

Konstituciâ Kyrgyzskoj Respubliki, www.gov.kg/?page_id=263\&lang=ru (dostęp: 10.12.2018).

Konstituciâ (Osnovnoj zakon) Rossijskoj Socialističesǩoj Federativnoj Sovetskoj Respubliki (utverždena postanovleniem XII Vserossijskogo S"ezda Sovetov ot 11 maâ 1925 g.), http://constitution.garant.ru/history/ussr-rsfsr/1925/red_1925/185477/chapter/3c1d312a9c6c4a13a02d7 900fa6f03a9/ (dostęp: 8.12.2018).

Konstituciâ (Osnovnoj Zakon) Soûza Sovetskih Socialističeskih Respublik (utverždena II S "ezdom Sovetov Soûza SSR ot 31 ânvarâ 1924 g.), http://constitution.garant.ru/history/ussr-rsfsr/1924/ red_1924/5508660/(dostęp: 8.12.2018).

Konstituciâ (Osnovnoj zakon) Soûza Sovetskih Socialističeskih Respublik (utverždena postanovleniem Črezvyčajnogo VIII S"ezda Sovetov Soûza Sovetskih Socialističeskih Respublik ot 5 de- 
kabrâ 1936 g.), http://constitution.garant.ru/history/ussr-rsfsr/1936/red_1936/3958676/ (dostęp: 8.12.2018).

Konstituciâ Respubliki Armeniâ, http://www.parliament.am/legislation.php?sel=show\&ID=1\& lang=rus (dostęp: 9.12.2018).

Konstituciâ Respubliki Belarus', Minsk 1994.

Konstituciâ Respubliki Kazahstan, http://www.constitution.kz (dostęp: 10.12.2018).

Konstituciâ Respubliki Tadžikistan, http://www.president.tj/ru/taxonomy/term/5/112 (dostęp: 10.12.2018).

Konstituciâ Respubliki Uzbekistan, http://constitution.uz/ru/clause/index (dostęp: 10.12.2018).

Konstituciâ RSFSR 1918 goda, Moskva 2003.

Konstituciâ Turkmenistana, http://turkmenistan.gov.tm/?id=11808 (dostęp: 10.12.2018).

Konstytucja Federacji Rosyjskiej, wstęp A. Bosiacki, Warszawa 2000.

Konstytucja Gruzji, wstęp G. Kuca, M. Grzybowski, Warszawa 2015.

Konstytucja Republiki Mołdawii, wstęp B. Zdaniuk, Warszawa 2014.

Konstytucja Ukrainy, wstęp E. Toczek, Warszawa 1999.

Konstytucja (Ustawa Zasadnicza) Związu Socjalistycznych Republik Radzieckich, Warszawa 1977.

\title{
Constitutional duties in the post-Soviet countries
}

\author{
Summary
}

The duties, along with rights and freedoms, define the legal status of the person in the state. However, the scientific literature pays more attention to the rights and freedoms, since they are considered as more important. The following paper tackles the issue of constitutional duties in the post-Soviet republics. The investigation has both qualitative and quantitative character and presents results in a comparative way.

Keywords: post-Soviet countries, constitutional law of post-Soviet countries, constitutional duties, comparative law. 